\title{
解の部分固定により探索空間を縮小するメタ戦略の検討 一巡回セールスマン問題への適用*
}

\author{
沼田 一道†・岩倉 行信
}

\author{
Experiments of a New Meta-Heuristics to Reduce the Search \\ Space by Partially Fixing of the Solution Values \\ - Application to Traveling Salesman Problem*
}

Kazumiti Numata ${ }^{\dagger}$ and Yukinobu IwAKurA ${ }^{\ddagger}$

\begin{abstract}
In this paper we present a new meta-heuristic approach to the traveling Salesman problem (TSP) and evaluate its performance. Proposed method reproduces and selects a population of local optima searched by random start modified Lin-Kernighan $(\mathrm{mLK})$ method. It enhances the search power and efficiency of mLK by fixing the part of the solution whose values coincide each other and thus reducing the search space of solutions. Results of numerical experiments on TSPLIB95 (500 or so cities instances) show that it is superiorly competitive to existing meta-heuristic methods for TSP. The reason of enhanced search power is also investigated through obserbation of its search processes.
\end{abstract}

\section{1.はじめに}

$N P$-困難な組合せ最適化問題に対しては，できるだけ 良い解を許容時間内に求める近似解法が重要な意味をも つ. 近年，コンピュータの演算速度の向上を背景に，余 裕の生じた演算時間を利用して近似解の精度を能率よく 高める様々な方法一メ夕戦略一の研究が盛んである [10]. メ夕戦略は, その性質が充分解明されていない問題に対 し, 一般的な局所探索 (逐次改善) 法の精度を手軽に向 上させる枠組みとして用いられる. 一方, 問題の構造を ふまえた高精度の発見的解法においても, 得られる解の 精度を少しでも改善するため様々なメ夕戦略が試みられ ている. 本論文では,「探索中に現れた複数個の良い解を 保持・更新し，その共通部分を固定して探索空間を徐々 に限定していくメ夕戦略（RSB 戦略）」[8]をとりあげ, 後者の状況におけるその効果を実験的に検証する。

沼田ら [8] は 2opt 法を基本探索法とした RSB 戦略 (RSB-2opt 法) を提案し，小規模の対称巡回セールスマ

\footnotetext{
* 原稿受付 2003 年 4 月 7 日

$\dagger$ 東京理科大学 工学部 経営工学科 Department of Management Science, Fuculty of Engineering, Tokyo University of Science; 1-3 Kagurazaka, Shinjuku-ku, Tokyo 162-8601, JAPAN

‡（株）アルファシステムズ Alpha Systems Inc.; 3-32-13 Tsuruyacho, Kanagawa-ku, Yokohama city, Kanagawa 221-0835, JAPAN
}

Key Words: meta-heuristics, TSP, modified Lin-Kernighan method, reduction of search space.
ン問題（TSPLIB95[9] の中の 50１00 都市程度の問題 例）に対する実験結果から，探索の精度が $20 p t$ 法のみの 場合と比べて大幅に改善されることを報告している。一 方, 対称巡回セールスマン問題 (symmetric Traveling Salesman Problem: 以下 TSP とよぶ）に対する局所探 索法としては, Lin-Kernighan 法 [4]（以下 LK 法とよ ぶ）が有名である。この LK 法を基本探索法として,「LK 法で求まる局所最適解に小変更を加えて LK 法を施す」 ことを繰返し行う iterated-Lin-Kernighan 法 [2]（以下 i-LK 法とよぶ) や chained-Lin-Kernighan 法 [6] (以下 c-LK 法とよぶ）が高精度の解法として知られている. i/c-LK 法の用いているメ夕戦略は「局所反復戦略」と総 称されている1.

本論文では，LK 法の一種である変形 Lin-Kernighan 法 [5]（以下 $\mathrm{mLK}$ 法とよぶ）を基本探索法とした RSB 戦略の変形版 $\left(\mathrm{RSB}^{*}-\mathrm{mLK}\right.$ 法) を提案し, mLK 法に局 所反復戦略を適用したi-mLK 法と比較した。 RSB*戦 略は多数の解を保持するという点で遺伝的アルゴリズ ム (以下 GA とよぶ) と似ている. TSP向けの GA とし ては「枝組立交义による遺伝的アルゴリズム」[7]（以下 GA-EAX 法とよぶ）の精度の高さが注目されるが，こ れとの比較も行った. TSPLIB95 中の問題例, att532 お

\footnotetext{
${ }^{1}$ Helsgaun[1] は感度解析を用いて候補枝集合を選定す る LK 法 (LKH 法とよぶ) を提案し，この LKH 法に 局所反復戦略を適用した解法が非常に精度の高いこと を報告している。
} 
よび rat575 に対して, RSB*-mLK 法と i-mLK 法を同 じ時間だけ実行した場合の比較結果，および，文献 [7]に 示されている結果との比較は, RSB*戦略（RSB*-mLK 法）が既存の定評ある戦略（解法）に十分匹敵しうるこ とを示している.

以下，2節では，基本探索法として用いる $\mathrm{mLK}$ 法を概 観する. 3 節で, RSB*戦略と RSB*-mLK法を提案する。 4 節では, RSB*-mLK 法の実行結果を示し, i-mLK 法, GA-EAX 法などと比較する. 5 節では, RSB*-mLK 法 がうまく機能する理由をその探索過程の観察を通して考 察する. 6 節は結論である。

\section{2. 巡回セールスマン問題と mLK 法}

TSP は，訪問対象となるすべての都市を 1 度ずつ訪 問して出発した都市に戻るような巡回路の中で, 距離や 時間に基づく移動費用の総和が最小となるものを求める 問題である。代表的な組合せ最適化問題の一つであり, $N P$-困難な問題のクラスに属する。

訪問対象の都市を $1,2, \ldots, n$, 都市 $i$ から都市 $j$ への移 動費用を $c_{i j}(i, j=1,2, \ldots, n)$ とするとき, TSP はつぎ のように定式化される.

$$
\text { (TSP) } \begin{cases}\text { minimize } & \sum_{i=1}^{n-1} c_{\sigma[i] \sigma[i+1]}+c_{\sigma[n] \sigma[1]} \\ \text { sub. to } & \sigma \in \mathcal{S}_{n}\end{cases}
$$

ただし $\mathcal{S}_{n}$ は $1,2, \ldots, n$ の置換全体の集合をあらわす。本 論文では, 費用行列 $C=\left(c_{i j}\right)$ がすべての $i, j$ について $c_{i j}=c_{j i}$ である “対称 TSP”を扱う.

TSP に対する発見的解法は, 現在の巡回路（現在解） を構成する枝のうち $k$ 本を別の枝で置き換え，巡回路の コストが改善されれば，その巡回路（次の現在解）へ移 行することを繰り返す $k \mathrm{opt}$ 法が基本である．交換する 枝の本数をしかるべき基準に基づいて制御する LK 法 [4] はその発展形であり, 実行速度と得られる解の精度の点 で定評がある。たた [4]の記述はやや抽象的で，実装上 の自由度が多少残る。本研究では, LK 法の一変種であ る $\mathrm{mLK}$ 法 [5] を基本探索法として採用する.

\subsection{Algorithm mLK}

mLK 法は, LK 法の第 1 レベルの代替探索を省略し， その代わりに，探索の各レベルに打いて， linkbase（現 在の巡回路を構成する枝で, 最初に除去対象となるもの) の両端点に接続する枝を取入れ枝候補として扱うこと で探索の幅を拡げたものである1. $\mathrm{mLK}$ 法 (LK 法) の 基本動作は，取入れ枝と除去枝を 1 組ずつ重ね合わせた 2-opt 操作 (2 本の枝を交換して巡回路長の変化を見る) の連鎖からなる. 初期巡回路 $\sigma=\left(s_{1}, s_{2}, s_{3}, \ldots, s_{n}\right)$ が 与えられたとき, その探索過程（逐次改善）の概略は以 下のと扔りである。

\footnotetext{
${ }^{1} \mathrm{LK}$ 法では片側に接続する枝のみを対象としている。
}

step 0 改善対象の巡回路 (ctour) を ctour $:=\sigma$ とする. step 1 最大改善量 (bestGain) を $-\infty$ とする.

2-opt 情報格納スタック $(m v S E Q)$ を空とする. 操作対象巡回路 $(\tau)$ を ctour とする. (Fig. 1) call mLK-step $(1,0) \quad \%$ 1:レベル, 0:累積改善量 (結果はbestGain, mvSEQ と $i_{\text {best }}$ に残る)

step 2 bestGainが正の場合, $m v S E Q$ に残された 2-opt 動作を ctour に施し，得られた巡回路を新たな ctour として step 1へ.

bestGain が 0 以下（改善不能）の場合，現在の ctourを1つずらす（linkbaseの位置を1ずらす）。 step 3 ctourのどの枝を linkbase とする探索でも改善不 能となればstep 4へ.さもなければstep 1へ. step 4 ctour に2-opt 改善（可能なら）を加えたものを $\mathrm{mLK}$ 法の局所最適解とする.

step 1 でよばれる手続き mLK-step(level, cumGain) は, level を増減させながら交換すべき枝を再帰的にバッ クトラック探索する．第 $i$ レベル $($ level $=i)$ の $\mathrm{mLK}$ step が対象とする巡回路 $\tau^{(i)}=\left(t_{1}^{(i)}, t_{2}^{(i)}, \ldots, t_{n}^{(i)}\right)$ を, 便宜的に $\tau=\left(t_{1}, t_{2}, \ldots, t_{n}\right)$ と表記する. また, 仮の $2 \mathrm{opt}$ 操作を施した次のレベルの対象巡回路を $\tau^{\prime}$ で表す。第 1 レベル開始時は $\tau^{(1)}=\tau=$ ctour である.

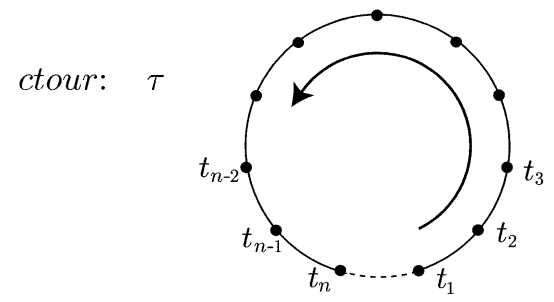

Fig. 1 Current tour

手続き mLK-step はつぎのように記述される。

procedure mLK-step( level, cumGain ) create ALIST; $\quad / *|A L I S T| \leq$ breadth(level)*/ if cumGain > bestGain then begin

bestGain $:=$ cumGain; $i_{\text {best }}:=$ level -1 ; end;

while $A L I S T \neq \emptyset$ do begin

let $(B v, P v)$ be the first element of $A L I S T$; (remove it from $A L I S T$ )

if $B v=t_{1}$ then begin $\quad / * t_{i} \equiv t_{i}^{(l e v e l)} * /$ $g 1:=c\left[t_{n}, t_{1}\right]-c\left[t_{1}, P v\right]$ $g 2:=c[P v, \operatorname{pred}(P v)]-c\left[\operatorname{pred}(P v), t_{n}\right] ;$

end else begin

$$
\begin{aligned}
& g 1:=c\left[t_{1}, t_{n}\right]-c\left[t_{n}, P v\right] \\
& g 2:=c[P v, \operatorname{next}(P v)]-c\left[n \operatorname{ext}(P v), t_{1}\right]
\end{aligned}
$$

end;

incrGain $:=\max \{g 1, g 2\}$; 
testGain $:=$ cumGain + incrGain;

$g:=g 1+g 2$

if testGain > bestGain then begin $\operatorname{do}-2 o p t((B v, P v), \tau) ; /{ }^{*} \tau \rightarrow \tau^{\prime *} /$ add $(B v, P v)$ to the end of mvSEQ; call mLK-step $($ level +1 , cumGain $+g)$; undo-2opt $\left((B v, P v), \tau^{\prime}\right) ; /^{*} \tau \leftarrow \tau^{\prime * /}$

end; $\quad \quad^{*} \tau \equiv \tau^{(\text {level })}, \tau^{\prime} \equiv \tau^{(\text {level }+1) * /}$

if bestGain $>0$ then RETURN

else begin

delete the added element from the end of $m v S E Q$;

end ;

end; /* of while */

RETURN

end. $/ *$ of procedure */

mLK-step は Fig. 2 に示す 2-opt 操作の繰返しにより探 索 (改善) を行う。一連の探索は, 直前レベルの 2-opt 操作で最後に加えた枝を, 次のレベルの 2-opt 操作の 最初に取り除く枝 (linkbase) として進める. 第 $i$ レベ ルでの 2-opt 操作における linkbase を $d^{(i)}$, 付加する 枝を $a^{(i)}$ ，除く枝を $b^{(i)}$ ，最後に加える枝を $x^{(i)}$ とす る。ここで, $d^{(i)}=x^{(i-1)}$ である. $d^{(i)}$ が決まっている ので， $a^{(i)}$ を決めると $b^{(i)}$ と $x^{(i)}$ は一意に決まる。第 $i$ レベルにおいては，取入れ枝を width $(i)$ 本試みる。取

$\operatorname{do}-2 o p t((B v, P v), \tau) \quad$ in the case $B v=t_{1}$
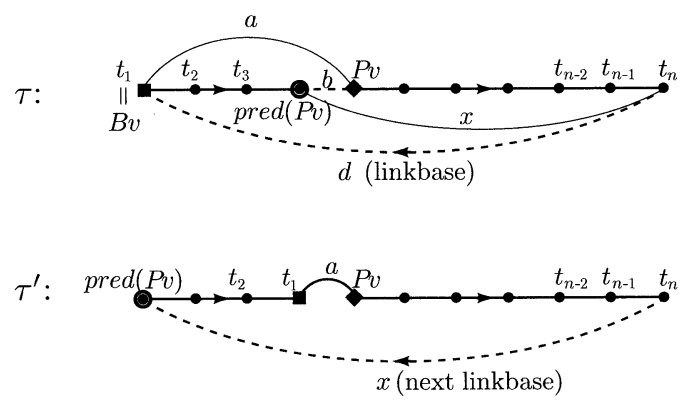

$\operatorname{do}-2 o p t((B v, P v), \tau) \quad$ in the case $B v=t_{n}$

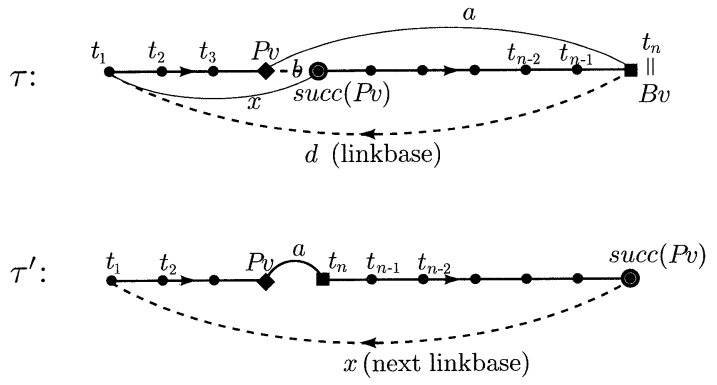

Fig. 2 mLK move from linkbase $\left(t_{n}, t_{1}\right)$
入れ枝は linkbaseの一方の端点 $B v\left(\in\left\{t_{n}^{(i)}, t_{1}^{(i)}\right\}\right)$ と巡 回路 $\tau^{(i)}$ において $B v$ の両隣以外に位置する点 $P v$ と の対 $(B v, P v)$ で指定する. mLK-step が第 $i$ レベルに 進んだとき，後述の基準により，breadth $(i)$ 個の点対 $\left(B v_{1}, P v_{1}\right),\left(B v_{2}, P v_{2}\right), \cdots,\left(B v_{w i d t h(i)}, P v_{w i d t h(i)}\right)$ から なるリスト $A L I S T(i)$ を作成して，後のバックトラック に備える。

第 1 レベルの mLK-step から戻ったとき, bestGain が正であれば， mvSEQに記録された（bestGain を実 現する）一連の 2-opt 操作を実際に施して ctour 更新 する。非正の場合には，つぎの linkbase（の除去）から 始まる探索を行う。第 1 レベルの linkbase は（一般性を 失うことなく) $\left(t_{n}^{(1)}, t_{1}^{(1)}\right)$ としている.

\subsection{2-opt 連鎖の制御}

枝 $u$ の移動費用を $c[u]$ と書くと, 2 -opt の連鎖を $m$ 回 行った後の累積改善量は

$\operatorname{cumGain}(m)=c\left[d^{(1)}\right]-\sum_{i=1}^{m} c\left[a^{(i)}\right]+\sum_{i=1}^{m} c\left[b^{(i)}\right]-c\left[x^{(m)}\right]$ で与えられる。ただし cumGain $(0)=0$ とする.

$a^{(i)}$ を取入れ枝とする $i$ 回めの 2-optを行うか否かは, それがもたらす可能性のある改善量

$\operatorname{incrGain}(i)=\max \left\{c\left[d^{(i)}\right]-c\left[a^{(i)}\right], c\left[b^{(i)}\right]-c\left[x^{(i)}\right]\right\}$ を指標として判定する。すなわち, $i$ 回めまで行ったと きの予想累積改善量

testGain $(i)=\operatorname{cumGain}(i-1)+\operatorname{incrGain}(i)$

と $i-1$ 回めまでに達成された最大の改善量

を比較して，

bestGain $(i-1)=\max _{1 \leq j \leq i-1} \operatorname{cumGain}(j)$

testGain $(i) \leq \operatorname{bestGain}(i-1)$

であれば他の取入れ枝候補を試し，候補がなければレベ ル $i-1$ に戻る（連鎖の停止）。そうでなければ取入れ枝

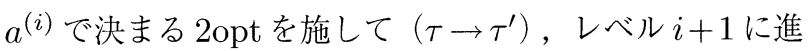
む。上のレベルから戻ったとき, bestGainが正であれ ば，さらに戻る。 bestGainが0以下の場合，ALIST $(i)$ に残り要素があれば, その先頭要素を $a^{(i)}$ として当該レ ベルの mLK-step の動作を復帰再開し, バックトラック を試みる.ALIST $(i)$ に残り要素がなければ下のレベル へ戻る．第 1 レベルから戻るとき，mLK-step は終了し て, step 4 の実行に移る.

\section{$2.3 \quad A L I S T$}

操作対象巡回路 $\tau^{(i)}$ (linkbase $d^{(i)}$ は $\left(t_{n}^{(i)}, t_{1}^{(i)}\right)$ ) に対し て, 取入れ枝 $a^{(i)}$ の候補は, $2(n-3)$ 本ある. incrGain $(i)$ の計算, 取入れ枝 $a^{(i)}$ の決定のためには, これらを全走査 する必要があるが，実行時間短縮のため，Pv (linkbase 側でない方の $a^{(i)}$ の端点) として, $t_{1}^{(i)}$ あるいは $t_{n}^{(i)}$ と

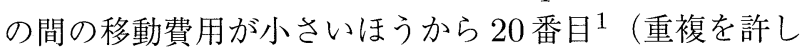
て合計 40 点）までの点を走査対象とする。ただし, 現

参考文献 [5]による. 
在に至る 2-opt 連鎖で，取入れ／除去枝の端点になった 点は走查対象から除く.この中から，

$$
\text { Gain }=\max \left\{c\left[d^{(i)}\right]-c\left[a^{(i)}\right], c\left[b^{(i)}\right]-c\left[x^{(i)}\right]\right\}
$$

の大きい順にbreadth $(i)$ 個を選んで, ALIST $(i)$ を作 $3^{1}$. 点対 $(B v, P v)$ の情報により 2-opt 動作を完全に復 元できるので, $m v S E Q$ にはこれを格納していく.

breadth $(i)$ は mLK 法のパラメータであり, 参考文献 [5]では, breadth $(1)=$ breadth $(2)=5$, breadth $(i)=1$ $(i=3,4, \ldots)$ と与えている. 我々もそう設定した.

\section{RSB* *戦略と $\mathrm{RSB}^{*}-\mathrm{mLK}$ 法}

参考文献 $[8]$ で示された RSB 戦略はつぎの通りである. [RSB 戦略]

step 1 問題のサイズを $s:=n$ とする.

step 2 ランダムに選んだ初期解を逐次改善して局所最適 解を求めることを, $L$ 回行う.

step $3 L$ 個の局所最適解から目的関数值の良いものを $q$ 個選び出す. 1 番目と 2 番目に良い解の間に一致 した部分がなければ step 2 へ戻る. (これの連続 生起が一定回数に達したら停止する)

step 4 目的関数值の良いほうから順に, 解の一致部分を 抽出し, $q$ に達するか一致部分がなくなる（直前） までの一致部分を固定し，問題のサイズを縮小す る. ( $s$ を更新する $)$

step 5 問題のサイズが十分小さくなったら step 6 に進 む。そうゔなければ，縮小された問題を新たな問 題として, step 2 に戻る.

step 6 今まで得られた最良の解を出力する.

[8]はこの戦略を用いて TSP を解いた。局所探索（逐次 改善）法として 2-opt法を用い, $L=100 \sim 400, q=5$ 11 で，100都市程度以下の問題例に適用し，良好な実験 結果を報告している.しかし，この方法をそのまま都市 数の大きな問題に適用すると, 4.2 節で見るように，実 行時間と精度の点で壁にぶつかる。

そこで，より大きな問題（TSP）に耐えられるよう， RSB 戦略をつぎのように変更する.

（1）精度の高い解を比較的少数保持する.

（2）親世代の各解（巡回路）を構成する枝集合の共通部 分を「緩く」固定し，探索を限定する。

(3) 子世代の解は, 親世代の解と共通（合併）枝集合の 情報とランダム性を加味して初期解を作り，それを 逐次改善して生成する。

（4）親世代から子世代へ一斉に交代するのではなく, 両 世代の解全体から評価值の良いものを半分残して （集団サイズを一定に保って）次世代の親とする.

\footnotetext{
${ }^{1} A L I S T$ の要素は点対 $(B v, P v)$ である. Gain $\leq 0$ の ものは格納しないので, ALIST の要素数はたかだか breadth 個である.
}

(1)は，(3)における逐次改善に $\mathrm{mLK}$ 法を用いることで 対処する。(2)は, RSB 戦略のように共通枝を完全に固 定して問題を縮小寸るのではなく, mLK 法の実行過程 で，固定されている linkbaseからの探索を省略すること により探索の能率化を図る。(4)は，GAの不完全世代交 代と同様で，良い解の情報を失わないようにしている.

(3) の初期解作成については, 予備実験を行って 3 通 りの方法を検討した．まず，(a)共通枝を固定し，それ以 外の部分をランダムにつなぎ合わせて初期解を与える方 法を試した。この方法は [8] で用いられたもので, RSB 戦略として最も素朴（自然）なものであるが，保持する 解が少数で問題のサイズが大きい（500 都市程度）と， 探索の集中（枝固定）が進まず，ランダム多スタート戦 略と同程度の精度しか達成されなかった。つぎに，(b) 合併枝集合（集団内のいずれかの巡回路で用いられた枝 集合から共通枝集合を除いたもの）を利用する方法を検 討した，共通枝集合の要素を固定し，合併枝集合の要素 をランダムに選んで初期巡回路を構成してみたが，時間 のかからない簡便な方法では, 合併集合に属さない（も ちろん共通枝集合にも含まれない）枝をかなり多く取り 込まざるを得ず，(a) と同様探索の集中（枝固定）は進 まなかった，最後に，(c) 親世代の各解にランダムな「小 変更」を加えたものを初期解とする方法を試みた。この 方法だと探索の集中（枝固定）が順調に進み，得られる 解の精度も高かった，以上の観察をふまえ，本研究では (c)を採用することにした.

(c)に打ける「小変更」(「突然変異」) は, 親巡回路のラ ンダムな箇所に Fig. 3 のような枝交換（double bridge） を（1回以上）施すことで実現した. double bridgeは参 考文献 [4]で導入されたもので, LK (mLK) 法の操作で は実現できない変更を巡回路にもたらす効果がある。変 更箇所には共通枝集合（固定枝）の部分も含めることと した．探索の途中までは固定枝を除外したほうが集中が 早く進み探索時間が多少短くて済むが，探索の終盤では 固定枝も変更対象に含めたほうが若干精度が良かったか らである。これは間違って固定された枝を解除する機会 が増すからであろう。

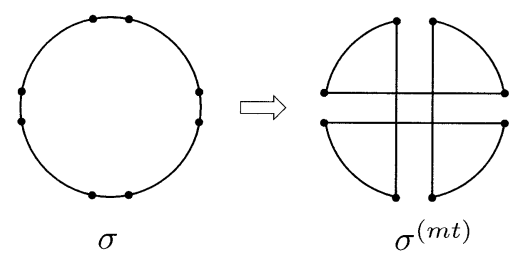

Fig. 3 Double-bridge

次節で扱う i-mLK 法でも double bridge を用いている. また，小変更で (1度に) 行う double bridge の回数に ついては次節で検討する。

変更された RSB 戦略と $\mathrm{mLK}$ 法を組み合わせた TSP に対する RSB*-mLK 法はつぎのように書ける。 
$\mathrm{RSB}^{*}-\mathrm{mLK}$ 法

step $0 k$ 個の初期解（初期巡回路）からなる集合 $\boldsymbol{S}=$ $\left\{\sigma^{(1)}, \sigma^{(2)}, \ldots, \sigma^{(k)}\right\}$ を生成する.

step $1 S$ の各要素 $\sigma$ に局所最適化法 (mLK 法+2-opt 法）を適用し，得られた $k$ 個の局所最適解（局所 最適巡回路）で $\boldsymbol{S}$ を置き換える.

step $2 \boldsymbol{S}$ の $k$ 個の巡回路に共通して含まれる枝の集合 $E_{\text {and }}$ を求める.

step $3 \boldsymbol{S}$ の各巡回路にランダムな double-bridge 操作 を施し， $k$ 個の反復初期解を生成する。 反復初期 解の集合を $\boldsymbol{S}_{m t}$ で表す.

step $4 \boldsymbol{S}_{m t}$ の各要素に $\mathrm{mLK}$ 法を適用する．このとき， $E_{\text {and }}$ に属する枝は第 1 レベルの linkbase として 使用しない. 適用後の各巡回路を 2-opt 法でチェッ クし(必要があれば) さらに改善した局所最適解 の集合を $\boldsymbol{S}_{n e w}$ とする.

step $5 \boldsymbol{S} \cup \boldsymbol{S}_{n e w}$ の $2 k$ 個の要素から巡回路長の短い $k$ 個 (best $k$ ) を選び，それらを新たな $\boldsymbol{S}$ とする.

step 6 終了条件を満たしていればstep 7 , さもなけ ればstep 2 へ行く.

step $7 \boldsymbol{S}$ の中の最良解を近似解とする. 停止.

RSB*-mLK 法は，「局所反復戦略」を“並列に”実行 し，そこから得られる共通枝集合 $E_{\text {and }}$ の情報を利用し て探索のさらなる集中化と, 複数解の保持による探索 の分散（安定化）を同時に行うものである。ここでいう “並列実行” は比喻的であるが，物理的に並列化すること も自然かつ容易と考えられる。

戦略のパラメー夕は, 集団サイズ $k$, 何らかの停止基 準（本論文では，「S 中の最良解が連続して $r$ 回更新され なければ停止する」としている)，およびdouble-bridge を施す回数 \# $d b$ （1ないし 2 回）だけである.

\section{4. 比較実験}

提案した RSB*-mLK 法の性能を $20 p t$ 法を用いた RSB 戦略と RSB*戦略 (それぞれ RSB-2opt法, RSB*-2opt 法とよぶ），同一の mLK 法を用いたi-mLK 法，および， 同様に集団的 (多点) 探索を行う GA-EAX 法と比較す る. 実験は, PC-AT 互換機（Pentium 1GHz，メモ リ128MB, Windows 2000, Delphi 5）の上で行った.

\subsection{RSB*-mLK 法の実行結果}

TSPLIB95 の中の att532 と rat575を対象とした RSB*-mLK 法の実行結果を Table 1 に示す。“params” の列は「 $\lceil k-r-\# d b 」 を, ~ “ a v e r a g e ” の$ 列は 30 回の試行に おける (各試行の) 最終巡回路長の平均と最適巡回路長 からの平均相対誤差 (百分率) を, “\#opt” の列は $(30$ 回の試行中）最適解を得た回数を示す. att532（532 都 市）は都市配置に偏りのある問題例，rat575（575 都市） は一様にランダムな都市配置の問題例である。
Table 1 Results of RSB*-mLK (30 trials)

\begin{tabular}{|c|c|c|c|}
\hline \multicolumn{4}{|c|}{ att532(optimum: 27686) } \\
\hline & params & average & \#opt \\
\hline \multirow{9}{*}{$\mathrm{RSB}^{*}$} & $40-40-1$ & $27698.7(0.046 \%)$ & 9 \\
\hline & $40-80-1$ & $27697.9(0.043 \%)$ & 11 \\
\hline & $80-40-1$ & $27693.5(0.027 \%)$ & 17 \\
\hline & $80-80-1$ & $27692.5(0.023 \%)$ & 18 \\
\hline & $40-40-2$ & $27692.8(0.024 \%)$ & 17 \\
\hline & $40-80-2$ & $27692.8(0.024 \%)$ & 17 \\
\hline & $80-40-2$ & $27691.3(0.019 \%)$ & 21 \\
\hline & $80-80-2$ & $27691.3(0.019 \%)$ & 21 \\
\hline & $100-40-2$ & $27687.7(0.006 \%)$ & 26 \\
\hline \multicolumn{4}{|c|}{ rat575(optimum: 6773 ) } \\
\hline & params & average & \#opt \\
\hline \multirow{9}{*}{$\mathrm{RSB}^{*}$} & $40-40-1$ & $6775.2(0.032 \%)$ & 1 \\
\hline & $40-80-1$ & $6774.8(0.027 \%)$ & 3 \\
\hline & $80-40-1$ & $6774.2(0.018 \%)$ & 3 \\
\hline & $80-80-1$ & $6773.8(0.011 \%)$ & 11 \\
\hline & $100-100-1$ & $6773.3(0.004 \%)$ & 24 \\
\hline & $40-40-2$ & $6774.8(0.027 \%)$ & 2 \\
\hline & $40-80-2$ & $6774.4(0.020 \%)$ & 4 \\
\hline & $80-40-2$ & $6774.2(0.017 \%)$ & 5 \\
\hline & $80-80-2$ & $6773.6(0.009 \%)$ & 12 \\
\hline
\end{tabular}

まず, 集団サイズ $k$, 非更新継続回数 $r$, double-bridge 適用回数 \# $d b$ を，それぞれ $(40,80),(40,80),(1,2)$ の 2 水準に設定して計 8 通りを実行した. Table 1 からは, $k$ の増加が (問題に関係なく) 解の精度向上をもたらして いることを確認できる. att532に対しては $r$ を大きくし ても精度はあまり変わらないが，\#dbを1から 2 にする と精度が向上する，att532では都市配置に偏りがあるの で, ある局所最適解とそれを改善する他の局所最適解と の距離が（mLK 探索の尺度で）大きい局面が少なから ずあり, 現在解に対する大きな変更は, そのような場合 の移行の可能性を増すからではないかと想像される。一 方, rat575に対しては\# $\# d b$ にって精度はあまり変わ らないが， $r$ を大きくすると精度は向上する，rat575で は都市配置がランダムに一様なので, 解空間においても 局所最適解が比較的単調 $(\# d b=1$ とした $\mathrm{mLK}$ 探索で 最適解までたどれる程度）かつ一様に存在すると思われ る.したがって，大きな $r$ で現在解の近くから何回も丁 寧に探すことは, 最適解に至る経路に乗るうえで効果が あると想像される。

以上の観察をふまえて，パラメータ「k-r-\#db」を， att532については「100-40-2」に, rat575については 「100-100-1」に設定して実行したところ, 得られる解の 精度は, かなり高い水準に達した。 


\subsection{RSB-2opt 法, RSB*-2opt 法との比較}

RSB*-mLK 法の出発点となった RSB-2opt 法の精度 を見ておく.まず， $L=300, q=5$ の RSB-2opt法で, att532 と rat575を 10 回ずつ解いた結果を Table 2 に 示す. length (巡回路長), error (相対誤差), etime (実行時間), \#2opt（2opt 実行回数）は10 回の平均で ある。

Table 2 Results of RSB-2opt (10 trials)

\begin{tabular}{|c|c|c|c|}
\hline Problem & length (error) & etime & $\# 2$ opt \\
\hline att532 & $28435.7(2.708 \%)$ & $966[\mathrm{~s}]$ & 21780 \\
\hline rat575 & $7045.6(4.025 \%)$ & $1038[\mathrm{~s}]$ & 21900 \\
\hline
\end{tabular}

10 試行の中の最良のものでも, att532 の場合, 相対誤 差 $1.93 \%$ （誤枝数 125 本）, rat575 の場合, 相対誤差 $3.09 \%$ (誤枝数 138 本) であり, Table 1 と比べると精度 は非常に低い。可能な範囲でパラメー夕を变えても，得 られる解の精度は有意には変わらない. RSB 戦略は「3 本以上連続して固定された枝の列」を点とみなして問題 そのものを縮小するが，実行過程を見るとこの縮約がな かなか進まず，半分のサイズ ( 250 都市前後) に縮小す るのに全体の 8 割程度の時間がかかっている.

50〜100 都市程度の問題に対して良好な結果を与えた RSB-2opt 法が，500 都市程度の問題に対してうまく働 かないのは,

(1) 2opt 法の探索能力が500 都市程度の問題に対しては 十分でなく,「良い解の共通部分を固定する」という 戦略が効果を発揮できない

（2）都市数が大きくなると縮約の回数が多くなり，誤つ て（最適解に含まれない枝を）固定する機会が増す ので,「共通枝を完全に固定して問題を縮小する」と いう戦略が有効でない

からだと考えられる．実際，多スタート $20 p t$ 法を 10 回 実行し得られる解（各回の最良のもの）の相対誤差を 調べたところ, att532 の場合, 各回 510 秒 ${ }^{1}$ (平均 7219 回の $2 \mathrm{opt}$ ）の探索で平均 $5.99 \%$ （最良で $5.72 \%$ ）程度, rat575 の場合, 各回 483 秒 ${ }^{1}$ (平均 6382 回の $2 \mathrm{opt}$ ）の 探索で平均 $8.06 \%$ （最良で $7.60 \%$ ）程度であった。これ らの問題に対して, RSB 戦略の効果は多スタート戦略の 相対誤差を半減させる程度に留まるといえよう。

上記 (2)に対する対策として，(a) 問題縮小に代わる探 索能率化の工夫，(b) 誤った枝固定を回復する機会の導 入，(c) 良い解を蓄積する不完全世代交代の採用，が考 えられる。この方向で構想されたのがRSB*戦略である.

基本探索法は 2 opt 法のままで戦略のみを RSB*にし た RSB*-2opt 法で同じ問題を解くと結果は Table 3 の ようになる。

戦略のパラメータは, どちらも, $k=r=80, \# d b=1$

${ }^{1} \mathrm{RSB}^{*}-\mathrm{mLK}: 40-40-1$ の att532 に対する所要時間が 510 秒, rat575に対する所要時間が 483 秒である.
Table 3 Results of RSB*-2opt (10 trials)

\begin{tabular}{|c|c|c|c|}
\hline Problem & length (error) & etime & \#2opt \\
\hline att532 & $27916.1(0.831 \%)$ & $988[\mathrm{~s}]$ & 40136 \\
\hline rat575 & $6881.8(1.606 \%)$ & $1303[\mathrm{~s}]$ & 46712 \\
\hline
\end{tabular}

とし,「探索の限定」は $20 p t$ 探索から固定枝を除外するこ とにより行っている. Table 1 には及ばないが，Table 2 と比べると精度はかなり高い. 10 回の試行のうち最良 のものの相対誤差は, att532の場合, $0.256 \%$ (誤枝数 66 本), rat575 の場合, $0.694 \%$ (誤枝数 108 本) であ る. $20 p t$ 探索の回数も同程度の時間で 2 倍くらいに達し ており，探索の能率化もある程度実現されている。しか し, 各試行の停止直前に扔いて固定されている枝の本数 は300 400 程度であり，探索の集中は十分に進んでい ないように思われる。この原因は $2 \mathrm{opt}$ 法の（都市数の 大きな問題に対する）精度の低さであろう. RSB*-mLK 法はこの 2opt 法を mLK 法に置き換えて, 精度を向上さ せたものである。

2opt 法の場合と同様, 多スタート mLK 法を 10 回 実行し得られる解の相対誤差を調べると, att532の場 合, 各回 510 秒 ${ }^{1}$ (平均 543 回の $\mathrm{mLK}$ ) の探索で平均 $0.536 \%$ （最良で $0.358 \%$ ）程度, rat575 の場合, 各回 483 秒 ${ }^{1}$ (平均 949 回の $\mathrm{mLK}$ ) の探索で平均 $0.681 \%$ （最良で $0.678 \%$ ）程度であった. Table 1 に示したRSB*-mLK 法の相対誤差は，これらの $1 / 10$ 以下になっている.

RSB*戦略は, 2opt法に対しても，mLK法に対して も，その探索能力を明確に強化しているが，単独でも精 度の高い $\mathrm{mLK}$ 法を基本探索法として用いた場合, 改善 の度合いはより大きい。

\section{$4.3 \mathrm{i}-\mathrm{mLK}$ 法との比較}

$\mathrm{mLK}$ 法（LK 法）を基本とする解法としては，局所 反復戦略を用いた i-LK法が有名である。この i-LK 法の LK 法部分を mLK 法に置き換えた i-mLK 法を実装し， RSB*-mLK法と比較する。

i-mLK法は時間の許す限り以下を実行するものである. step 0 初期巡回路をランダムに生成し，それを $\sigma$ とす る.さらに $\tau \leftarrow \sigma$ とする.

step $1 \tau$ に mLK 法を適用し, 適用後の巡回路を 2-opt 法 で最終改善したものを $\tau^{\prime}$ とする。

step $2 \tau^{\prime}$ と $\sigma$ の巡回路長の小さい方を $\sigma$ とする。 $\sigma$ にラ ンダムな double-bridge 操作を施した巡回路を $\tau$ として step 1へ戻る.

att532 と rat575 について, i-mLK 法を RSB*の所 要時間と同じ時間だけ実行した結果を Table 4 に示す. att532では, 反復の際に double bridge を 1 回施すもの と 2 回のものを試みた. 1 回のものをi1-mLK 法, 2 回 のものをi2-mLK 法とよび，それぞれ“i1”, “i2” と記す。 ただし, rat575に対してはi1-mLK法のみ行った。 
Table 4 Results of i-mLK under equal execution time to RSB*-mLK (30 trials)

\begin{tabular}{|c|c|c|c|}
\hline \multicolumn{4}{|c|}{ att532 (optimum: 27686 ) } \\
\hline e-time & $\# \mathrm{mLK}$ & average & \#opt \\
\hline $510[\mathrm{~s}] \quad \mathrm{i} 1$ & 1056 & $27706.0(0.072 \%)$ & 8 \\
\hline $\mathrm{i} 2$ & 858 & $27720.1(0.123 \%)$ & 0 \\
\hline $40-40-1$ & 3701 & $27698.7(0.046 \%)$ & 9 \\
\hline $601[\mathrm{~s}] \quad$ i1 & 1248 & $27706.0(0.072 \%)$ & 8 \\
\hline $\mathrm{i} 2$ & 1013 & $27717.1(0.112 \%)$ & 1 \\
\hline $40-80-1$ & 5601 & $27697.9(0.043 \%)$ & 11 \\
\hline $990[\mathrm{~s}]$ & 2077 & $27702.3(0.059 \%)$ & 10 \\
\hline $\mathrm{i} 2$ & 1678 & $27711.0(0.090 \%)$ & 3 \\
\hline $40-40-2$ & 4688 & $27692.8(0.024 \%)$ & 17 \\
\hline $1110[\mathrm{~s}] \quad \mathrm{i} 1$ & 2335 & $27702.2(0.059 \%)$ & 10 \\
\hline $\mathrm{i} 2$ & 1884 & $27709.4(0.090 \%)$ & 4 \\
\hline $80-40-1$ & 6917 & $27693.5(0.027 \%)$ & 17 \\
\hline $1216[\mathrm{~s}]$ & 2562 & $27702.2(0.058 \%)$ & 10 \\
\hline & 2065 & $27705.7(0.071 \%)$ & 5 \\
\hline $40-80-2$ & 6288 & $27692.8(0.024 \%)$ & 17 \\
\hline $1265[\mathrm{~s}]$ & 2667 & $27702.2(0.058 \%)$ & 10 \\
\hline $\mathrm{i} 2$ & 2149 & $27705.3(0.070 \%)$ & 5 \\
\hline $80-80-1$ & 10403 & $27692.5(0.023 \%)$ & 18 \\
\hline $2141[\mathrm{~s}] \quad$ i1 & 4542 & $27699.7(0.049 \%)$ & 12 \\
\hline $\mathrm{i} 2$ & 3653 & $27703.8(0.064 \%)$ & 6 \\
\hline $80-40-2$ & 8520 & $27691.3(0.019 \%)$ & 21 \\
\hline $2460[\mathrm{~s}] \quad$ i1 & 5226 & $27699.4(0.048 \%)$ & 12 \\
\hline & 4204 & $27703.3(0.063 \%)$ & 8 \\
\hline $80-80-2$ & 11843 & $27691.3(0.019 \%)$ & 21 \\
\hline $2902[\mathrm{~s}] \quad$ i1 & 6173 & $27699.4(0.048 \%)$ & 12 \\
\hline & 4965 & $27702.9(0.061 \%)$ & 8 \\
\hline $100-40-2$ & 10970 & $27687.7(0.006 \%)$ & 26 \\
\hline & 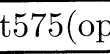 & mum: 6773) & \\
\hline e-time & $\# \mathrm{mLK}$ & average & \#opt \\
\hline $483[\mathrm{~s}] \quad$ i1 & 2024 & $6780.3(0.108 \%)$ & 1 \\
\hline $40-40-1$ & 4300 & $6775.2(0.032 \%)$ & 1 \\
\hline $582[\mathrm{~s}] \quad$ i1 & 2446 & $6780.0(0.103 \%)$ & 1 \\
\hline $40-80-1$ & 6365 & $6774.8(0.027 \%)$ & 3 \\
\hline $952[\mathrm{~s}] \quad$ i1 & 4031 & $6779.1(0.090 \%)$ & 2 \\
\hline $80-40-1$ & 8016 & $6774.2(0.018 \%)$ & 3 \\
\hline 1214 [s] i1 & 5141 & $6778.9(0.087 \%)$ & 2 \\
\hline 80-80-1 & 13029 & $6773.8(0.011 \%)$ & 11 \\
\hline $1617[\mathrm{~s}]$ & 6853 & $6778.7(0.084 \%)$ & 2 \\
\hline 100-100-1 & 19910 & $6773.3(0.004 \%)$ & 24 \\
\hline
\end{tabular}

平均実行時間（単位は秒）を示す “e-time”の列には， 対応する RSB*法のパラメータを記した. “\#mLK”の列 は，i-mLK 法あるいはRSB*法で行われた mLK探索の 回数を示している. RSB*法の場合は，保持する $k$ 個の
解それぞれに対する探索回数を合計したものである。し たがって, \# $\mathrm{mLK} / k$ が平均世代数であり, 最終解はこ れより $r$ 世代前に現れている。“average”の列は，30回 の試行における平均巡回路長と平均相対誤差 (百分率), “\#opt”の列は最適解を得た回数である.

Table 4 は，i-mLK 法（特にi1）の精度が定評通り良 好であることを示している. mLK 法の探索能力は局所 反復戦略により明確に強化されている。

att532に対してはi1-mLK 法の精度がi2-mLK 法の精 度を有意に上回っており，Table 1 に示した RSB*-mLK 法の場合とは振る舞いが異なる。これは，i-mLK 法の場 合 1 点（1つの解）しか保持しないので，探索が相対的 に不安定になりやすい（解空間において探索が集中する 部分の「良し悪し」のバラツキが相対的に大きい）から だと思われる。そのような状況では，近くの解を丁寧に 探す（i1-mLK 法）方が安定しており，良い解に至る可 能性が高いということであろう。また mLK 探索の回数 も i1-mLK 法のほうが 2 - 3 割多い. RSB*-mLK 法の場 合 $\# d b=2$ の方が結果が良いのは，少し遠い解（から） の探索を行っても多点探索により安定性が保たれ，より 広く探すことの効果が出るからではないかと思われる.

i-mLK 法と RSB*-mLK 法の結果を比較すると， 2 つ の問題の，すべての実行時間において，明確に後者の精 度が上回っている。その差は実行時間を増やしても縮ま らず，むしろ広がる傾向にある ${ }^{1}$. 同一の mLK 法を基 礎とし同様に反復する両解法の精度の差は, つぎのよう な点で RSB*戦略がうまく機能しているからだと考えら れる。

(1) 探索空間の縮小（固定枝を mLK 探索の linkbase か ら除外すること）による探索能率の向上. Table 4 で示したように, RSB*-mLK 法における mLK探索 の回数は i-mLK 探索の $2 \sim 3$ 倍に達している。この 差は，多数の枝が固定され $\mathrm{mLK}$ の所要時間が小さ くなった RSB*反復の終盤で生じている. 結局, 最 適解にかなり近づいた局面であまり時間をかけずに 多くの探索が行われることになり，良い解が得られ る可能性が高くなる。

(2) 多点探索による探索の分散と淘汰による探索の集 中. 多数の解を保持することにより, 解空間を幅広 く探索し, 淘汰によって良い解の存在する方向に集 団を導く。これは (1) の探索に安定性を与える. 実 際，Table 4 からわかるように, RSB*-mLK 法は i-mLK 法と比べて得られる解のバラツキが小さい.

こここで比較対象としているのは本節の冒頭に示した i-mLK 法である，与えられた時間いっぱい続ける代わ りに適当なところで反復を打ち切り, (同時間で) 試行 数を増やすことによって, 平均精度を改善することは 可能かもしれない. 30 試行中, 最終解の得られた反復 回数 (経過時間) の平均は, att532（i1-mLK 法）で, 1262 回（577 秒）である. 


\subsection{GA-EAX 法との比較}

メ夕戦略を用いた TSP 向けの解法として, GA-EAX 法 [7]の精度の高さも注目される。GA-EAX法は枝組立 交叉により子世代生成を行う GAの一種であり，動作の 概略は以下の通りである。

step $0 N_{\text {pop }}$ 個のランダムな初期巡回路を生成し，それぞ れに 2-opt法を施したものを初期集団 $C$ とする.

step $1 C$ から非復元抽出により $N_{p o p} / 2$ ペアの両親をつ くる.

step 2 各両親（巡回路 $A, B ） に$ 対して,下記の枝組立交 叉を $N_{\text {cross }}$ 回施し $\left(N_{\text {cross }}\right.$ 個の) 子巡回路を生 成する. 両親を加えた $N_{\text {cross }}+2$ 個の巡回路の中 から最良の 2 個を選んで $\left(N_{\text {pop }} / 2\right.$ 個のペアにつ いてこれを行い）次世代の $C$ を構成する.

step 3 終了条件を満たせば終了.さもなければstep 1 一 戻る.

ここで，親巡回路 $A, B$ に含まれる枝の集合を $E_{A}, E_{B}$ とする。また， $A$ に含まれて $B$ に含まれない枝の集合を $E_{x o r}^{(A)}, B$ に含まれて $A$ に含まれない枝の集合を $E_{x o r}^{(B)}$ と する，枝組立交叉はつぎのように行われる。

step 2-1 枝集合 $E_{x o r}^{(A)} \cup E_{x o r}^{(B)}$ から, $E_{x o r}^{(A)}$ の要素と $E_{x o r}^{(B)}$ の要素が交互に現れるランダムな閉路 $X_{A}+X_{B}$ $\left(X_{A} \subset E_{x o r}^{(A)}, X_{B} \subset E_{x o r}^{(B)}\right)$ を生成する.

step 2-2 $X_{A}, X_{B}$ をもとに $E_{A}-X_{A}+X_{B}\left(E_{B}-X_{B}+\right.$ $X_{A}$ ）を作る。これは全都市を覆う部分巡回路 の集合（緩和個体）となる。

step 2-3 この緩和個体を 2-opt 法に類似の局所探索操作 で完全な巡回路に修正して子巡回路とする.

親巡回路に共通して含まれる枝全体と，どちらか一 方の親に含まれる枝を基礎としてできるだけ短い巡回 路を生成する過程を「交叉」としてとらえるのが EAX の着想である. Table 5 に GA-EAX 法の実行結果 [7] を引用した。 "params” の列は「 $N_{\text {pop }}-N_{\text {cross }} 」$ を示す. “average” の列と “\#opt” の列は, 30 回の試行における 最終巡回路長の平均精度と最適解到達回数である.

Table 5 Results of GA-EAX [7] (30 trials)

\begin{tabular}{|c|c|c|c|}
\hline \multicolumn{4}{|c|}{ att532 (optimum: 27686) } \\
\hline & params & average & \#opt \\
\hline \multirow{4}{*}{ EAX } & $250-10$ & $27696.7(0.039 \%)$ & 3 \\
\hline & $250-100$ & $27691.4(0.020 \%)$ & 12 \\
\hline & $250-500$ & $27689.9(0.014 \%)$ & 15 \\
\hline & $250-1000$ & $27691.5(0.020 \%)$ & 13 \\
\hline \multicolumn{4}{|c|}{ rat575 (optimum: 6773) } \\
\hline & params & average & \#opt \\
\hline \multirow{3}{*}{ EAX } & $300-10$ & $6775.4(0.035 \%)$ & 1 \\
\hline & $300-100$ & $6774.2(0.017 \%)$ & 8 \\
\hline & $300-500$ & $6774.0(0.015 \%)$ & 10 \\
\hline
\end{tabular}

Table 1に扔けるパラメータ“100-40-2”（att532）と “100-100-1”（rat575）の RSB*-mLK 法の結果は, 集団 サイズを 250（att532）あるいは300（rat575）とした EAX で $N_{\text {cross }}$ を変化させて解いたすべての結果を上

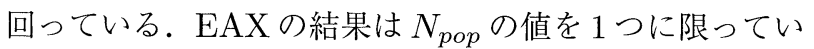
るし，実行時間もも考慮しなくてはならないので簡単には 比較できないが， RSB*-mLK 法の性能は GA-EAX 法 に十分匹敵するものと思われる。

\section{5. 実行過程}

4.3 節で指摘した (1)，(2) に関連して, RSB*-mLK 法の実行過程を観察する。まず， 1 反復当りの所要時 間（の推移）をFig. 4 (att532 に対する RSB*-100-402) と Fig. 5 (rat575 に対する RSB*-100-100-1) に示 す. 30 回の試行のうち, 反復回数が最少（a:att532: 80 回，c:rat575: 149 回）および最多（b:att532: 160 回， d:rat575: 265 回）のもののみ示した. 試行により繰返し 回数は変化するが, 所要時間推移の傾向はあまり変わら ない. 例外的に固定枝の本数が少ないまま終了する試行 (att532で 2 回ほど見られた) では，少し大きめの所要 時間で横ばいになる。

つぎに，探索の安定性について観察できたところを 記す。まずatt532であるが，30 回の試行中，17 回は初 回反復以降 1 度も誤って固定することなく最終的に 530 本の枝を固定して最適解に達し終了している. 便宜上, 各試行の過程を“(誤固定枝の最大本数, 誤固定出現回 数)”の対で表現すると, 残り 13 回中 9 回は $(1,2),(1,5)$, $(3,1),(3,4),(3,21),(4,11),(5,7),(5,17),(11,2)$ で あり, 最終的に 530 本の枝を固定し最適解に達して終了 している．枝の誤固定を回復するうえで, mLK法の 2 レ ベル以上の探索に加えて, double bridge 2 回の突然変 異が貢献していると思われる. 最適解に達しなかった 4 回のうち 2 回は 527 本の枝を固定し（そのうち 19 本は誤 固定）, 巡回路長 27693 で終了している. 比較的早い回 （10１9 反復目）から 1 3 本の詔固定が始まり，徐々に その数を増やして，19本に至る。この解は最適解から枝 数で 21 本分離れた局所最適解である。ただし，実験の 中で att532には少なくとも2 2のの最適解があることが 確認された。両者は枝 3 本分 (3-opt 近傍) の距離にあ る。したがって「19本」も「21本」も目安である. 残り

\footnotetext{
1参考文献 [7] では $\operatorname{rat575を~} N_{p o p}=300, \quad N_{\text {cross }}=100$ で解いた場合の所要時間（563 秒）しか報告されて いない. 実験は Pentium $200 \mathrm{MHz}, 64 \mathrm{MB}$ 上の Soralis2.5.1/GNU Cで行われている. RSB*の実行時間 は Table 4 に示すとおりである.EAX の終了条件や 問題・パラメータが変わったときの所要時間が不明で あり, OS, 言語処理系, デー夕構造の洗練度が異なる (可能性がある) ので不確定要素を含むが, 同一条件下 での所要時間の違いは数倍以内と推測される.
} 


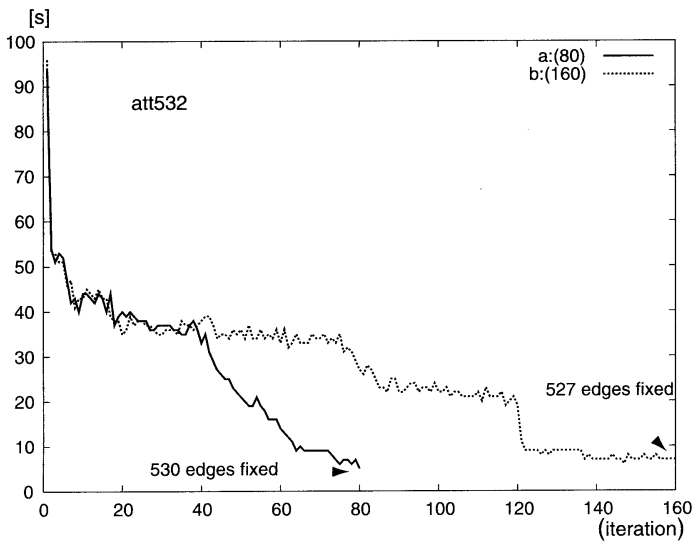

Fig. 4 The time required for an iteration (att532: 100-40-2)

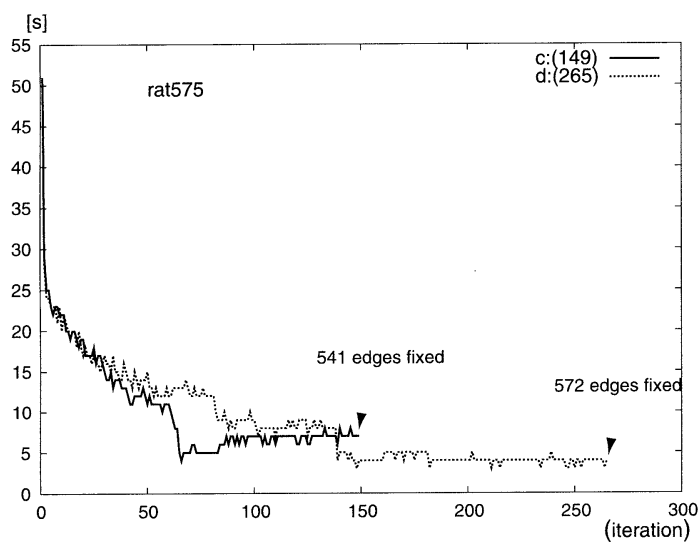

Fig. 5 The time required for an iteration

(rat575: 100-100-1)

2 回のうち 1 回は, 438 本の枝を固定し（そのうち誤固 定 10 本）巡回路長 27705 で終了している.この場合は 解集団中に，枝数で互いに76 本 (78 本) 分離れた巡回 路長 27705 の 2 つ局所最適解が現れてしまい, それ以 上枝固定が進まず，また，そこからの脱出もできなかっ たものである.もう 1 回は, 472 本の枝を固定し（その うち誤固定 29 本）巡回路長 27703 で終了している。 こ の場合も解集団中に, 枝数で互いに $15,13,12,10$ 本 分離れた巡回路長 27703 の複数の局所最適解が現れてし まい，それ以上枝固定が進まず，また，そこからの脱出 もできなかったものである.

rat575の探索過程は,「比較的一様な振舞いの中に, 細 かいバラツキがある」という印象である。これは, 解空 間中に巡回路長 $6774,6775,6776$ などの局所最適解が 多数存在し1, double bridge による捸動と mLK探索に

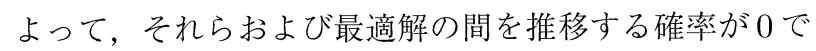

\footnotetext{
${ }^{1}$ たとえば，巡回路長 6774 を与える巡回路（解）は少な くとも21個は存在する。 それらと最適解の間の枝距離 は11〜36にわたる。ただし rat575の場合にも少なく とも二つの最適解が存在する. 両者は枝 2 本分 $(2-\mathrm{opt}$ 近傍）の距離にある.
}

はないという事実によって裏付けられる2.

30 回の試行のうち最初の 10 回分余の探索過程の最終 段階を観察した。10 回中 8 回が最適巡回路長 6773 に達 し, 2 回（第 3 試行と第 7 試行）は 6774 で終わってい $る^{3}$. 第 $1 ， 4 ， 5 ， 9$ 試行では最良巡回路長 $=6774$ の状 態を $22 \sim 34$ 回繰り返している. その後半では保持する 100 個の解すべてが巡回路長 6774 である.このとき, 相 異なる解の個数は平均 8 18 程度確保されている. 最適 解からの距離は，第 1 試行の場合 $24 \sim 32$ とやや大きい が，第 $4 ， 5 ， 9$ 試行では（1，2の例外を除き）11〜19で ある. 固定枝数は 536 ～ 566 で徐々に増え，誤固定数は 2〜19の範囲で変動する。幅広い（安定な）探索が行わ れているといえよう。第 $2,6,8$ 試行では最良巡回路長 $=6774$ の状態を $61 \sim 84$ 回繰り返している. その約 $3 / 4$ の期間は保持する 100 個の解すべてが巡回路長 6774 で ある。このとき, 保持している相異なる解は（数回の例 外を除き） 2 個, 最適解からの距離は 16 １9 であった. 固定枝数は 572 , 誤固定数は 16 である.この状態での探 索はi-mLK とほぼ同等であるが，延べ $6100 \times(3 / 4)$ $8400 \times(3 / 4)$ 回以上という多数の探索により, 最適解に 達したと考えられる。第 10 試行は巡回路長 6779,6777 , 6775 と，ほとんど誤固定なしに，固定枝を 425４92 と 増やしていき, 55 回目の反復で最適解を発見している. この間の相異なる解の保持数は $25 \sim 30$ である. 第 3,7 試行では, 最良巡回路長 $=6774$ の状態を 100 回繰り返し てそのまま終了している。 そのうち，84～85 回は保持す る 100 個の解すべてが巡回路長 6774 である.このとき, 保持している相異なる解の保持数は $12 \sim 15$, 最適解から の距離はほとんどが 27 ～ 35 であった. 固定枝数は 532 566 , 誤固定数は $7 \sim 26$ である. 解集団に保持された解 が最適解から大分離れているため, 最適解に達しなかっ たのであろう ${ }^{4}$.

最終段階に至る探索過程では, 相異なる解の保持個数 はずっと多く，幅広い（安定な）探索が行われている.

\footnotetext{
${ }^{2} \mathrm{RSB}$ *戦略はこの推移確率を補強している。

3 ほかに, 第 14,28 試行が 6774 , 第 13 試行が 6775 , 第 27 試行が 6776 である。

4 第 11 試行以後の最適解に達しない場合は以下の通り である. 第 13,28 試行は第 3,7 試行に類似している. それぞれ, 最適解から枝数で 29〜34 離れた巡回路長 6775 の解，25３6 離れた巡回路長 6774 の解が集団中 の多数を占めるに至り，その状態で終了している．第 14 試行は第 $2,6,8$ 試行とまったく同様の経過をたど るが，6773に達する前に終了した場合である．第 27 試行は最良巡回路長が 6776 に達したとき，すでに 30 本以上の誤固定をしている。この後，570本の枝を固 定し（誤固定 38）, 最適解からの距離が 39 43 の解 （相互距離 $2 ， 3 ， 5 ） に$ 収束して終了する.
} 


\section{6. おわりに}

本論文では参考文献 [8] で示された「多数の局所最適 解を保持・淘汰し，それらの一致部分の固定により探索 精度・能率の向上を図るメ夕戦略 (RSB)」を，より大 きなサイズの問題に対応できるよう改変した戦略 RSB* を提案し, 標準的な組合せ最適化問題である TSP に適 用してその性能を評価した。適用に際しては, mLK 法 の採用により基盤となる解の精度を確保し, mLK 探索 の一部省略と突然変異を用いた次世代解の生成により探 索空間の縮小を行っている.

提案した RSB*-mLK 法のメ夕戦略部分は簡単なもの であるが, ベンチマーク問題集 TSPLIB95 の中の 600 都 市程度までの問題例に対し, 安定的に非常に大きな探索 精度向上効果のあることが確認された. att532 と rat575 問題に対する結果の比較からは, RSB*-mLK 法の精度 が，GAの枠組みで枝組立交叉を行う GA-EAX 法 [7]に 十分匹敵し, 局所反復戦略のもとで mLK 法を繰り返す i-mLK 法を明確に上回ることがわかった。後者との精 度の差は RSB*戦略の正味の有効性を示すものと考えら れる。

$\mathrm{RSB}^{*}-\mathrm{mLK}$ 法がうまく働く理由として，(1)「探索空 間の縮小（固定枝を mLK 探索の linkbase から除外する こと）による探索能率の向上」と，(2)「多点探索による 探索の分散と淘汰による探索の集中」の 2 つを推定した。 $\mathrm{RSB}^{*}-\mathrm{mLK}$ 法の実行過程の観察結果はこれらの仮説を 支持している. RSB*-mLK 法は, 多数の解を保持しそ の共通部分を固定することで安定 (頑健) かつ能率的な 探索を実現し, その結果, 精度の高い解を得ることに成 功していると思われる.

TSP の実行可能解（巡回路）は, 部分巡回路を含ま ず，各点の接続枝数が 2 (枝数=点数）の枝集合である. したがって，ある巡回路（現在の解）から，しかるべき 複数の枝をそれと共有し, 全体としてはそれと異なる新 しい巡回路を生成するには, 若干の工夫が必要である. GA-EAX 法の枝組立交叉は二つの解をもとにこれを行 うものであり, i-mLK 法の突然変異（局所反復）は一つ の解をもとにこれを行う. 本論文では後者を借用したが, 3. 節の (3-b) の方向で工夫する余地があるかもしれない.

以下は今後の課題である.

(1) RSB*-mLK 法における次世代巡回路生成法の改良

(2) 1000 都市以上の TSP を扱うための戦略の再検討や 実装技術の改善

(3) RSB*戦略の TSP 以外の問題への適用

\section{謝辞}

有益なコメント，ご指摘を下さった査読者の方々に感 謝いたします。

\section{参 考文 献}

[1] K. Helsgaun: An effective implementation of the LinKernighan traveling salesman heuristic; European Journal of Operational Research, Vol. 126, pp. 106$130(2000)$

[2] D.S. Johnson: Local optimization and the traveling salesman problem; Proceedings of 17th Colloquium of Automata, Languages, and Programming, Lecture Notes in Computer Science, Vol. 443, SpringerVerlag, pp. 446-461 (1990)

[3] S. Lin: Computer solutions of the traveling-salesman problem; BSTJ, Vol. 44, pp. 2245-2269 (1965)

[4] S. Lin and B.W. Kernighan: An effective heuristic algorithm for the traveling-salesman problem; Operations Research, Vol. 21, pp. 498-516 (1973)

[5] K.-T. Mak and A.J. Morton: A modified LinKernighan traveling-salesman heuristic; Operations Research Letters, Vol. 13, pp. 127-132 (1993)

[6] O. Martin, S.W. Otto and E.W. Felten: Large-step Markov chains for TSP incorporating local search heuristics; Operations Research Letters, Vol. 11, pp. 219-224 (1992)

[7] 永田, 小林: 巡回セールスマン問題に対する交叉：枝 組み立て交叉の提案と評価; 人工知能学会誌, Vol. 14, pp. 88-99 (1999)

[8] 沼田, 児玉: 解の淘汰により变数の固定を行う探索法に ついて; システム制御情報学会論文誌, Vol. 12, No. 6, pp. 375-377 (1999)

[9] G. Reinelt: TSPLIB95, http://www.iwr.uni-heidelberg.de/groups/comopt/ software/TSPLIB95/ (1995)

[10] 柳浦, 茨木: 組合せ最適化一メ夕戦略を中心として一; 朝倉書店 (2001) 